\title{
MORPHOLOGICAL VARIATIONS OF SPLEEN: A CADAVERIC STUDY IN SOUTH INDIAN POPULATION
}

\section{Umarani $S^{* 1}$, Sivaraj $\mathbf{R}^{2}$, Ananthi ${ }^{3}$, Muniappan V ${ }^{4}$.}

${ }^{{ }_{1}}$ Assistant Professor, Department of Anatomy, Rajah Muthiah Medical College, Annamalai University, Annamalainagar, Tamil Nadu.

${ }^{2}$ Professor \& Head, Department of Pharmacology,Aarupadaiveedu Medical College\& Hospital, Kirumampakkam, Puducherry.

${ }^{3}$ Tutor, Department of Anatomy, Rajah Muthiah Medical College, Annamalai University, Annamalainagar, Tamil Nadu.

${ }^{4}$ Professor and Head, Department of Anatomy, Rajah Muthiah Medical College, Annamalai University, Annamalainagar, Tamil Nadu.

\section{ABSTRACT}

Background and aim: Spleen, a secondary lymphoid organ presents with wide variations in morphology. Size and weight of the spleen varies at different ages and different individuals and in the same individuals under different conditions. Further, a good knowledge about the morphological variations is very important to the physicians and surgeons for any pathological conditions of spleen. The aim of the present study was to find out the morphological variations of spleens particularly in the South Indian Population.

Materials and methods: A properly embalmed 40 cadaveric spleens were selected for the present study. The study was carried out in the Department of Anatomy, Rajah Muthiah Medical College,Annamalai University,Annamalai Nagar, Chidambaram, Cuddalore district, TamilNadu. The data were collected and statistical analysis was done. Results: The present study observed many variations in shapes and sizes of the spleen.

Conclusions: In healthy states the spleen is not palpable. However, enlargement of spleen (splenomegaly) that occurs in malaria, kalaazar, sarcoidosis and leukaemia it becomes palpable. The morphological variations of spleen in the present study will be useful to the physicians and surgeons in the diagnosis and treatment of various disorders of spleen.

KEY WORDS: Spleen, Accessory spleen, Splenomegaly, Lymphoid organ.

Address for Correspondence: Dr. S. Umarani , Assistant Professor, Department of Anatomy, Rajah Muthiah Medical College, Annamalai University, Annamalainagar, Tamil Nadu, India.

E-Mail: drsumarani@gmail.com

Access this Article online

Quick Response code

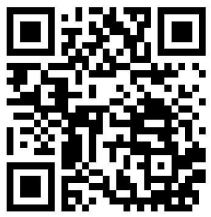

DOI: $10.16965 /$ ijar.2017.506

Journal Information

International Journal of Anatomy and Research

ICV for 2016
90.30
ISSN (E) 2321-4287 | ISSN (P) 2321-8967 https://www.ijmhr.org/ijar.htm DOI-Prefix: https://dx.doi.org/10.16965/ijar

\section{Article Information}

Received: 14 Nov 2017

Peer Review: 14 Nov 2017

Revised: None
Accepted: 02 Jan 2018

Published (O): 05 Feb 2018

Published (P): 05 Feb 2018

\section{INTRODUCTION}

Spleen, a secondary lymphoid organ, a deep red in colour, soft and pulpy in consistency in the living and belongs to vascular reticulo-endothelial system[1]. It lies between the greater curvature of the stomach and the left colic flexure anteriorly and the diaphragm behind. It occupies the left hypochondrium and extends from the scapular line behind where it exhibits a rounded (posterior) border that follows the curvature of the ribs with its long axis parallel to that of the left tenth rib and somewhat 
pointed anterior pole (extremity) situated in the midaxillary line. It has two surfaces, two borders and two poles. The posterior surface is convex and adapts itself to the concavity of the diaphragm and lies along the ribs 9, 10 and 11, which often leave deep indentations on it in the cadaver. The visceral surface presents four impressions produced by the related viscera. These are easily seen in the formalin fixed specimen and the areas are demarcated by well-marked ridges. The posterior pole usually related to the vertebral column whereas the broad anterior pole which is directed laterally. The spleen is rarely absent, but accessory spleens have been reported to occur in $10-35$ percent of individual [2]. The spleen is lobulated in the foetus, but the lobules normally disappear before birth. As per the superior border is concerned near the anterior pole in adults there may be one or two notches indicating the development from several lobes [3].

Shape of the spleen varies from a slightly curved wedge to a domed tetrahedron. Size and weight of the spleen varies at different ages and different individuals and in the same individuals under different conditions. In adults, it is usually $12 \mathrm{~cm}$ long, $7 \mathrm{~cm}$ broad and $3-4 \mathrm{~cm}$ wide, weighing around $150 \mathrm{gm}$ but it ranges from 80 to $300 \mathrm{gm}$ [1]. The spleen is not considered absolutely essential for an individual's survival [4]. However, a study on its morphology is still important due to its wide range of variations in morphology and haematological immunological functions. Further, a good knowledge about the morphological variations is very important to the physicians and surgeons for any pathological conditions of spleen $[5,6]$. In spite of quite a few studies on the morphological variations of spleen, still controversy exists about its morphology for decades. Therefore, the aim of the present study was to find out the morphological variations of spleens particularly in the South Indian Population.

\section{MATERIALS AND METHODS}

The present study was carried out in the department of Anatomy, Rajah Muthiah Medical College ,Annamalai University,Annamalai Nagar, Chidambaram, Cuddalore district, TamilNadu. Forty cadaveric spleens were selected for this study. Normal spleens from both sexes were added together and statistical analysis was done without considering the sexual dimorphism. Spleens were removed from the abdominal cavity, after detached from various attachments and splenic vessels were cut near the hilum. Debris and fatty tissues were cleaned meticulously with running tap water. We measured the lengths, breadths and widths of the spleens with the help of spreading and sliding callipers, the greatest distance between the anterior and posterior poles are considered as its length, then we considered the greatest distance between two points at the same level on the superior and inferior borders as its breadth and the greatest width was considered as width. The average weight of the spleen were weighed with the help of electronic weighing machine and also the shapes, poles, borders and surfaces of each spleens were observed. In the morphology, we observed the presence of splenic notches on the superior, intermediate and inferior borders. Accessory spleen if they were present, noted for at the hilum of the spleen.

Statistical analysis: The data collected from this study were tabulated, statistically analysed. The variations related to shapes, sizes were expressed as percentage. The statistical analysis of the data was performed in Systat version 12 .

\section{RESULTS}

The morphology of spleen was studied in 40 formalin fixed specimens. We found that variations in shapes, sizes and notches of spleens. Out of 40 spleens, 20 (50\%) were wedge shaped (Table 1/ Fig. 1), 6 (15\%) were triangular (Table 1/Fig.2), 5 (12.5 \%) were irregular (Table 1/ Fig.3), 4 (10\%) dome shaped (Table 1/Fig.4), 3 (7.5\%) oblong (Table 1/Fig.5) and 2 (5\%) were round shaped (Table 1/Fig.6). In 32 (80\%) specimens, splenic notches were found on superior border, in 15 (37.5\%) specimens the notches were found on inferior border, Only in 6 (15\%) specimens, the notches were found on intermediate border, in $10(25 \%)$ spleens notches were found on both superior and inferior borders, in 4 $(10 \%)$ spleens the notches were found on all borders and in $4(10 \%)$ spleens the notches were not found in any border(Table 2). In two 
specimens, deep notches were found on superior border (Fig. 7) and inferior border (Fig. 8). One specimen $(2.5 \%)$ showed nodular growth at the hilum of spleen (Fig.9) while another specimen $(2.5 \%)$ showed accessory spleen near hilum (Fig.10).

The length varied from $8 \mathrm{~cm}$ to $13 \mathrm{~cm}$ with an average length of $10.3 \mathrm{~cm}$. However, in most of the spleens, that is in 34 specimens (85\%), the length ranged from $8 \mathrm{~cm}$ to $12 \mathrm{~cm}$ (Table 3). Breadth of the spleens varied from $6 \mathrm{~cm}$ to 9.5 $\mathrm{cm}$ with an average breadth of $7.58 \mathrm{~cm}$. However, in $38(95 \%)$ specimens, the breadth was in the range of $6 \mathrm{~cm}$ to $9 \mathrm{~cm}$ (Table 4). The width varied from $1.3 \mathrm{~cm}$ to $3.6 \mathrm{~cm}$ with an average width of $2.65 \mathrm{~cm}$. In most of the spleen that is in $32(80 \%)$ specimens, the width ranged from 2 $\mathrm{cm}$ to $4 \mathrm{~cm}$ (Table 5). The weight of the spleen was in the range of 64.56 to 164.4 grams with an average weight of $98.07 \mathrm{grams}$. Most of the specimens that is $28(70 \%)$ specimens the weight ranged from 80 to $120 \mathrm{gm}$ (Table 6).

Table 1: Shapes of the spleen.

\begin{tabular}{|c|c|c|}
\hline Shapes & Number & $\%$ \\
\hline Wedge & 20 & $\mathbf{5 0}$ \\
\hline Triangular & 6 & $\mathbf{1 5}$ \\
\hline Irregular & 5 & $\mathbf{1 2 . 5}$ \\
\hline Dome & 4 & 10 \\
\hline Oblong & 3 & $\mathbf{7 . 5}$ \\
\hline Round & 2 & 5 \\
\hline
\end{tabular}

Table 2: Notches on the borders of spleen.

\begin{tabular}{|c|c|c|c|}
\hline Borders & $\begin{array}{c}\text { No. of } \\
\text { notches }\end{array}$ & $\begin{array}{c}\text { No. of } \\
\text { Spleens }\end{array}$ & $\%$ \\
\hline \multirow{4}{*}{ Superior border } & 0 & 8 & 20 \\
\cline { 2 - 4 } & 1 & 15 & 37.5 \\
\cline { 2 - 4 } & 2 & 12 & 30 \\
\cline { 2 - 4 } & 3 & 4 & 10 \\
\cline { 2 - 4 } & 4 & 1 & 2.5 \\
\hline \multirow{4}{*}{ Inferior border } & Total & 40 & 100 \\
\cline { 2 - 4 } & 0 & 25 & 62.5 \\
\cline { 2 - 4 } & 1 & 12 & 30 \\
\cline { 2 - 4 } & 2 & 3 & 7.5 \\
\hline \multirow{3}{*}{ Intermediate border } & Total & 40 & 100 \\
\cline { 2 - 4 } & 0 & 34 & 85 \\
\cline { 2 - 4 } & 2 & 4 & 10 \\
\cline { 2 - 4 } & Total & 2 & 5 \\
\hline \multicolumn{2}{|c|}{ Notches Present on sup. \& inf. Borders } & 10 & 25 \\
\hline \multicolumn{2}{|c|}{ Notches Present on all three borders } & 4 & 10 \\
\hline \multicolumn{2}{|c|}{ Notches Absent on all three borders } & 4 & 10 \\
\hline
\end{tabular}

Int J Anat Res 2018, 6(1.2):4914-19. ISSN 2321-4287
Table 3: Length of the spleen.

\begin{tabular}{|c|c|}
\hline Length of Spleen & $\%$ \\
\hline 8 to $10 \mathrm{~cm}$ & 50 \\
\hline 10 to $12 \mathrm{~cm}$ & 35 \\
\hline Above $12 \mathrm{~cm}$ & 15 \\
\hline
\end{tabular}

$\mathrm{N}=40 ;$ Mean $=10.3 \mathrm{~cm} ; \mathrm{SD}=1.25$

Minimum $=8 \mathrm{~cm} ;$ Maximum $=13 \mathrm{~cm}$

Table 4: Breadth of the spleen.

\begin{tabular}{|c|c|}
\hline Breadth of Spleen & $\%$ \\
\hline 6 to $7 \mathrm{~cm}$ & 50 \\
\hline 7 to $8 \mathrm{~cm}$ & 27.5 \\
\hline 8 to $9 \mathrm{~cm}$ & 17.5 \\
\hline Above $9 \mathrm{~cm}$ & 5 \\
\hline
\end{tabular}

$\mathrm{N}=40 ;$ Mean $=7.58 \mathrm{~cm} ; \mathrm{SD}=0.90$

Minimum $=6 \mathrm{~cm} ;$ Maximum $=9.5 \mathrm{~cm}$

Table 5: Width of the spleen.

\begin{tabular}{|c|c|}
\hline Width of spleen & $\%$ \\
\hline 1 to $2 \mathrm{~cm}$ & 20 \\
\hline 2 to $3 \mathrm{~cm}$ & 45 \\
\hline 3 to $4 \mathrm{~cm}$ & 35 \\
\hline Above $4 \mathrm{~cm}$ & 0 \\
\hline
\end{tabular}

$\mathrm{N}=40 ;$ Mean $=2.65 \mathrm{~cm} ; \mathrm{SD}=0.64$

Minimum $=1.3 \mathrm{~cm} ;$ Maximum $=3.6 \mathrm{~cm}$

Table 6: Weight of the spleen.

\begin{tabular}{|c|c|c|}
\hline Weight (gms) & $\begin{array}{c}\text { No. of } \\
\text { Specimen }\end{array}$ & $\%$ \\
\hline 60 to 80 & 8 & $\mathbf{2 0}$ \\
\hline 80 to 100 & 15 & $\mathbf{3 7 . 5}$ \\
\hline 100 to 120 & 13 & $\mathbf{3 2 . 5}$ \\
\hline 120 to 140 & 2 & $\mathbf{5}$ \\
\hline Above 140 & 2 & $\mathbf{5}$ \\
\hline
\end{tabular}

$\mathrm{N}=40 ;$ Mean $=98.07$ gms SD $=25.35$

Minimum $=64.56 \mathrm{gms}$ Maximum $=164.4 \mathrm{gms}$

Fig. 1: Wedge shaped spleen.

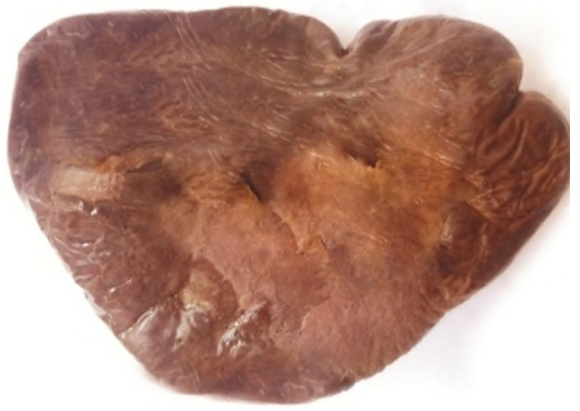

Fig. 2: Triangular shaped spleen.

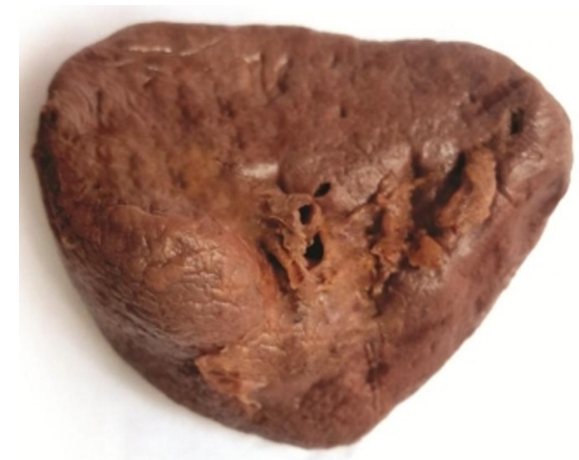


Fig. 3: Irregular shaped spleen

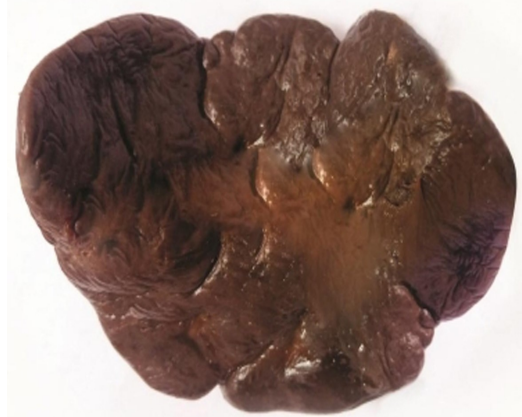

Fig. 6: Round shaped spleen.

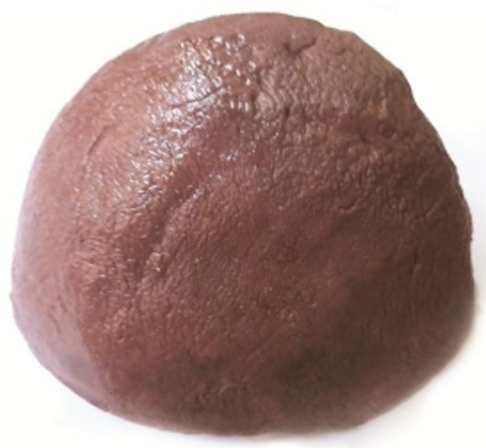

Fig. 9: Nodular growth at the hilum.

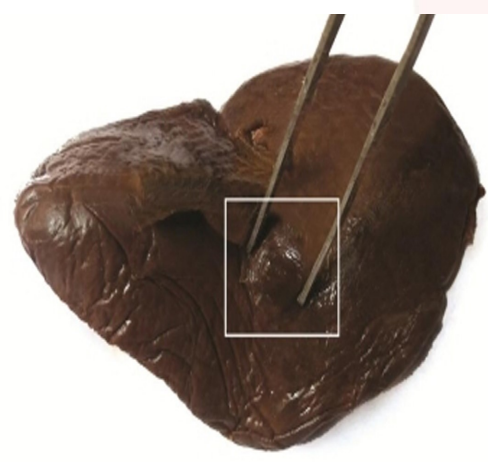

\section{DISCUSSION}

Spleen is a large lymphoid organ with wide range of functions. It plays a major role in the maturation and activation of lymphocyte and initiation of an immune response. It is also an organ of haemopoiesis in foetus [1]. It is with varied morphology and clinical significance as well as considerable controversies for centuries. In the present study, six different shapes of the spleen were observed. Among these, the most common one was the wedge shape (50\%) followed by triangular (15\%) and irregular shape (12.5\%). These variations are not consistent with the findings of previous studies. For instance, one study reported the wedge (61.26\%), the tetrahedral (21.6\%) and the triangular shapes $(12.61 \%)$ and another study observed that $61.26 \%$ was wedge shaped, $21.62 \%$ tetrahedral,
Fig. 5: Oblong shaped spleen.

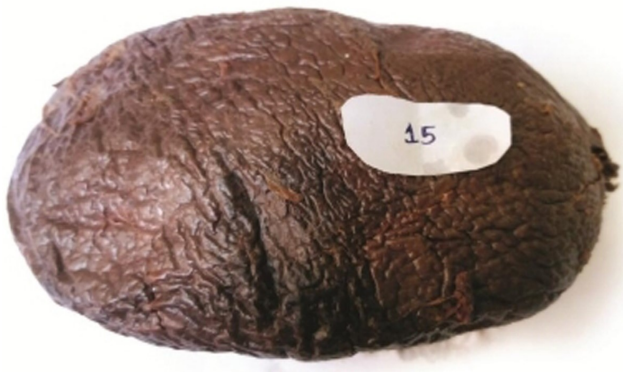

Fig. 8: Deep notch on the inferior border of spleen.

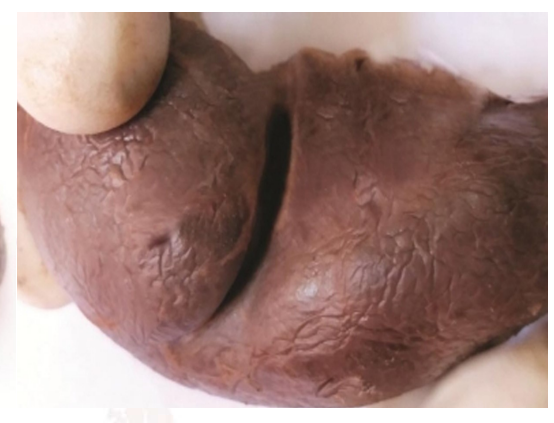

Fig. 10: Accessory spleen.

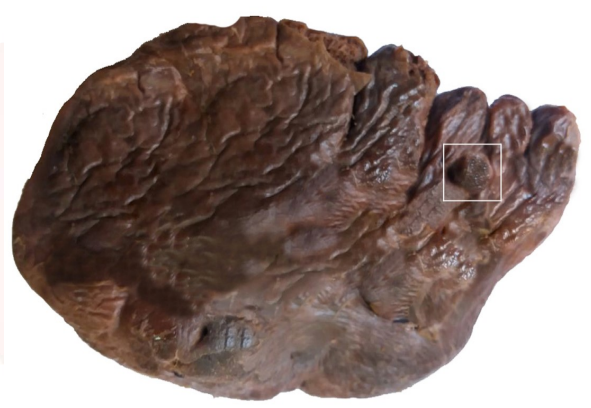

$12.61 \%$ triangular, $3.60 \%$ oval and $0.90 \%$ irregular shaped $[7,8]$. As opposed to the findings of these studies, additional dome shapes (10\%) oblong (7.5\%) and round shape (5\%) of the spleen were also noted in the present study.

In the present study the splenic notches were found on the superior, inferior and intermediate borders. The number of notches varied from 0-4, but commonly, there were one or two notches. These findings of the present study were in concurrence with the past study which found the presence of 0-4 splenic notches in their study on 100 spleens [9].They found a single splenic notch on the superior border of spleen in $98 \%$ and in 2 cases, the notch was present on the inferior border and in one specimen they observed on the intermediate border. Kawale et al found that 3 spleens (9.3\%) has multiple lobes and notches were present on the superior 
border of spleen, 4 spleens (12.5\%) deep notches on inferior, 2 spleens (6.2\%) showed deep notches on medial border and 1 spleen (3.1\%) was pyramidal shaped with presence of notch on inferior border [7]. These variations could be important as in splenomegaly, the anterior border, anterior part of diaphragmatic surface and notched superior border may become palpable below the left costal margin [10].

Nayak et al found from their study of 50 spleens, 25 spleens (50\%) were normal and had all the classical features mentioned in the text book with only $50 \%$ of splenic notches on the superior margin and 25 spleens (50\%) did not have any notches [11]. Two spleens (4\%) did not have hilum and 4 spleens ( $8 \%$ ) were small in size i.e. about 3 inches long. Contrary to these observations, the present study, we observed the splenic notches on the superior border in $80 \%$, inferior border $37.5 \%$ and Intermediate border only $15 \%$ specimens. Notches on both superior and inferior borders were observed in $25 \%$ and on all three borders $10 \%$ specimens. $10 \%$ of specimens notches were absent on all three borders. Lizamma Alex et al., mentioned the presence of notches in their study on 70 spleens [12]. They observed splenic notches on the superior border $90 \%$, inferior border $23 \%$ and on the intermediate border $41 \%$ of specimens. In the present study, we also observed in one specimen $(2.5 \%)$ a deep notch on the superior border of the spleen (Fig. 7). In another specimen a deep notch was found on the middle of the intermediate border to the inferior borders which extended towards the diaphragmatic surface, thus giving a lobulated appearance to the spleen (Fig.8). The variability in the notches and fissures is explained on the basis of development of the organ. The spleen develops from the mesoderm. During its development, different lobules are formed, which fuse with each other later on. The indication of the lobulation in adult spleen is its notched upper border [13]. Sometimes, this lobulated appearance may persist in the spleen $[3,13]$. That could explain for many notches present on the spleen, which can be seen on the superior as well as on the inferior borders.

In one of the specimens (2.5\%) a nodular growth was present at the hilum of spleen (Fig.9). In another sample accessory spleen which measures about $2 \times 2 \mathrm{~cm}$ found near the hilum of the spleen as pedunculated mass (Fig.10). The colour of the accessary spleen was identified like the colour of the spleen. During the development of the spleen, small masses of the splenic tissue may detach from the main mass and may develop in to accessory spleens [14]. In the present study, accessory spleen was found in one specimen. However, other studies reported the incidence of the accessory spleen was $10-35 \%$ [15-17]. The majority of accessory spleens occur at the hilum, in the greater omentum or along the splenic vessels and pancreas. Size of the accessory spleen is up to $3 \mathrm{~cm}$ in diameter and may undergo torsion. If the spleen is removed in case of haemolytic anaemia, a careful search must be made for accessory spleen, later on which can cause recurrent symptoms if not removed carefully [2].

In the present study the length of the spleen varied from 8 to $13 \mathrm{~cm}$ with an average of 10.3 $\mathrm{cm}$. The breadth varied from 6 to $9.5 \mathrm{~cm}$ with an average of $7.58 \mathrm{~cm}$ and the width ranged from $1.3 \mathrm{~cm}$ to $3.6 \mathrm{~cm}$ with an average of $2.65 \mathrm{~cm}$. The mean values of length, breadth and width of the spleen in our study were $10.3 \mathrm{~cm}, 7.58 \mathrm{~cm}$ and $2.65 \mathrm{~cm}$ respectively. One study reported the mean values of length, breadth and width which were $11 \mathrm{~cm}, 7 \mathrm{~cm}$ and $3 \mathrm{~cm}$ while another study found the mean values of length, breadth and width of the spleen were $9.66 \mathrm{~cm}, 6.22 \mathrm{~cm}$ and $3.06 \mathrm{~cm}$ respectively $[8,18]$. Similar to the earlier studies $[15,19]$, in the present study also weight of the spleen varied between $64.56 \mathrm{gm}$ and $164.4 \mathrm{gm}$ with an average of $98.07 \mathrm{gm}$. The average adult weight of the spleen is $150 \mathrm{gram}$ varies from 80-300gm [1]. Compared to the earlier studies which was done by Kawale Sugat et al the average weight of the spleen was $137.42 \mathrm{gms}$ and Chaware et al found that the average weight of spleen was $145.76 \mathrm{gms}[7,8]$.

The present study found the average weight was $98.07 \mathrm{gms}$ which was lower than earlier studies $[7,8]$. In the present study, the values of length, width and weight of spleen were slightly lower than normal and also those which were reported in previous studies. The reason of the morphological variations of the spleen particularly in the South Indian population was may be due to 
low socio economic status, food habits and body constitution [20].

\section{CONCLUSION}

In healthy states the spleen is not palpable. However, in enlargement of spleen (splenomegaly) as seen in malaria, kalaazar, sarcoidosis and leukaemia it becomes palpable. In such condition, the anterior border, anterior diaphragmatic surface and notched superior border become palpable below the left costal margin, the marginal notches are exaggerated and easily palpable. The morphological variations of spleen in the present study will be useful to the physicians and surgeons for palpating the spleen and therefore in the diagnosis and treatment of underlying disorders of spleen.

\section{Conflicts of Interests: None}

\section{REFERENCES}

[1]. Standring S: Gray's Anatomy: The Anatomical Basis of the Clinical Practice,39th edition. Edinburg; Elsevier Churchill Livingstone. 2006; 1239-44.

[2]. Lee McGregor's Synopsis of Surgical Anatomy. 12th edition. John Wright \& Sons Ltd. 1986 : 107-113.

[3]. Keith L.Moore,T.v.n Persaud. The digestive system. The developing Human: Clinically Oriented Embryology. $8^{\text {th }}$ ed. New yourk. New Delhi, Elsevier. 2008; 224.

[4]. Vasalius. A catalog of the H.Winnet Orr Historical collection. American college of surgeons; Chicago. 1960. Library of congress catalogue. Card number 60-11348.

[5]. Beauchamp RD, Holzman MD. Fafiam TC, Spleen. In: Townsend CM, Beauchamp RD. Evers BM, Mattox KL. eds. Sabiston Text book of surgery: The biological basis of modern surgical practice. Vol. 2 17th ed. Bangalore:Saunders Elsevier. 1994; 1679-1708.

[6]. Maier RV. Spleen. In: Mulholland MW, Lillemoe KD, Doherty GM, Maier RV, Upchurch GR Jr. eds. Greenfield's surgery: scientific principles and practice. 4th ed. Philadelphia: Lippincott Williams \& Wilkins. 2005.

[7]. Kawale Sugat G, Pandit S.V. Ganorkar Y.S.., Shaikh S.I., Meshram M.M. Morphological study of spleen IOSR - JDMS. 2016;15(8):15-21.
[8]. Chaware PN, Belsare SM, KulkarniYR, SudhirVishnupant, Ughade JM. The Morphological Variations of the Human Spleen. JCDR. 2012;6(2): 159-162.

[9]. Das S, AbdLatiff A, Suhaimi FH, Ghazalli H, Othman F. Anomalous Splenic notches: A cadaveric study with clinical implications. Bratisl Lek Listy. 2008;109;513-6.

[10]. John Macleod. Macleod's clinical examination, $12^{\text {th }}$ edition: Churchill Livingstone. 2009; 202.

[11]. Nayak BS, Somayajiand SN, soumya KV. A Study on the Variations of Size, Shape and External Features of the Spleen in South Indian Population. Int J Morphol. 2011;29(3): 675-677.

[12]. Lizamma Alex, Dr Anju George, Mrs Bency Xavier, SrPrincy Jacob, Mrs Kumari et al. Morphological Variations of Human spleen in different age groups. International Journal of Health care Sciences. 2015;3(I):122-29.

[13]. Sant S. Embryology for medical students. New Delhi: Jaypeebrothers Medical Publishers (p) Itd. 2002; 203-04.

[14]. Hamilton W.J Boyd JD, Mossman HW. Human embryology - prenatal development of form and function. 4th ed. London: The Macmillan press Ltd. 1978; 363-64.

[15]. Hollinshead WH. Anatomy for Surgeons, 3rd ed. vol2. New York: Harper and Row. 1982; 436-45.

[16]. Curtis GM, Movitz D, The Surgical significance of the accessory spleen. Ann Surg.1946; 123(2): 27698.

[17]. Emment JM, Dreyfuss ML. Accessory Spleen in the scrotum. Ann Surg.1943;117:754- 9.

[18]. Michels NA. The variational Anatomy of the spleen and the splenic artery. Am J Anat Anatomy. 1942;70:21-72.

[19]. Bergman R A, Adel K. Spleen anatomical variations, illustrated Encyclopaedia of human anatomic variations, opus-4; organ system; digestive system and spleen. (http://www.anatomyatlases.org/Anatomi cVariants/OrganSystem/Text/Pancreas.shtml)

[20]. Waghmode GT, Porwal SS, Shinde PB, Waghmode UT. Morphological analysis of variations of spleen. Int J Anat Res. 2017;5(2.1):3693-97.
How to cite this article:
Umarani S, Sivaraj R, Ananthi V, Muniappan V. MORPHOLOGICAL
VARIATIONS OF SPLEEN: A CADAVERIC STUDY IN SOUTH INDIAN
POPULATION. Int J Anat Res 2018;6(1.2):4914-4919. DOI:
10.16965/ijar.2017.506 